УДК 634.11:678.048

(C) 2013

Сердюк М. С., Гапріндашвілі Н. А., кандидати сільськогосподарських наук, Гогунська П. В., аспірант *

Таврійський державний агротехнологічний університет

\title{
ВПЛИВ ПОГОДНИХ УМОВ НА ФОРМУВАННЯ КОМПОНЕНТІВ ХІМІЧНОГО СКЛАДУ ПЛОДІВ СЛИВИ
}

\section{Рецензент - доктор сільськогосподарських наук В. В. Калитка}

\begin{abstract}
Досліджено вплив суми активних температур вище $10{ }^{\circ} \mathrm{C}$, кількості опадів та гідротермічного коефіиієнта (ГТК) на формування сухих розчинних речовин, органічних кислот, иукрів та аскорбінової кислоти плодів сливи. Результати кореляційного аналізу дають можливість стверджувати, щзо найбільш істотний вплив на формування показників хімічного складу плодів сливи в умовах південного Степу України мають не погодні умови всього вететаиійного періоду, а умови останнього місячя перед збиранням плодів, коли найбільш активно відбувається формування їх якості.
\end{abstract}

Ключові слова: плоди сливи, погодні умови, сухі розчинні речовини, цукри, кислоти, вітамін $C$.

Постановка проблеми. В останні роки плодівництво південного Степу України все частіше піддається впливу негативних абіотичних стресорів. У цій зоні все частіше спостерігаються критичні мінімальні температури взимку, заморозки у весняний період, посушливі періоди в другу половину літа. Надлишок або нестача тепла і кількості опадів у період вегетації плодових дерев призводить до негативних наслідків, які ведуть до порушення нормального функціонування рослин, погіршення хімічного складу i збереженості плодів. Тому вивчення особливостей погодних умов зони південного Степу України та їх впливу на процеси формування якості плодів має істотне значення для подальшого розвитку галузі плодівництва.

Аналіз останніх досліджень і публікацій, у яких започатковано розв'язання проблеми. Сучасна харчова технологія розглядає плоди як життєво необхідні продукти, поскільки вони є основним джерелом багатьох вітамінів, мінеральних солей, органічних кислот, ароматичних речовин і легко засвоюваних вуглеводів. Чимало речовин, що містяться в плодах, можуть не мати значення в харчовому відношенні, але визначають такі важливі властивості як стійкість до хвороб, передчасного дозрівання, а також їх леж- кість. Хімічний склад плодів і овочів залежить від багатьох факторів: їх сортових та видових особливостей, агротехніки вирощування, зони вирощування тощо [10].

За даними багатьох авторів, істотний вплив на формування хімічного складу мають погодні умови у вегетаційний період. Характеризуються вони сумою активних температур вище $10^{\circ} \mathrm{C}$, кількістю опадів, а також гідротермічним коефіцієнтом [4, 6]. Проте в літературних джерелах відсутні дані про влив цих погодних факторів на формування компонентів хімічного складу плодів, вирощених в умовах південного Степу України. У зв'язку з цим очевидна актуальність виявлення взаємозв'язку між зазначеними показниками.

Мета і завдання досліджень. Метою роботи було встановлення закономірностей формування компонентів хімічного складу плодів сливи у період вегетації.

Для реалізації поставленої мети було необхідним вирішити наступні завдання: проаналізувати погодні умови вегетаційного періоду; визначити вміст сухих розчинних речовин, цукрів, органічних кислот та вітаміну С у плодах сливи під час збирання; встановити взаємозв'язок між процесами формування компонентів хімічного складу плодів сливи у період вегетації та погодними умовами.

Матеріали і методика досліджень. Дослідження виконувалися в 2008-2011 pр. на базі кафедри «Технології переробки та зберігання продукції сільського господарства» Таврійського державного агротехнологічного університету. Для досліджень були обрані плоди сливи сорту Волошка, який внесено до реєстру сортів рослин, придатних для поширення в Україні [1], вирощені в умовах Дослідного підприємства «Дослідне господарство «Мелітопольське». Щоденні метеорологічні дані за період із 2008 по 2011 рр. зібрані на Мелітопольській метеостанції.

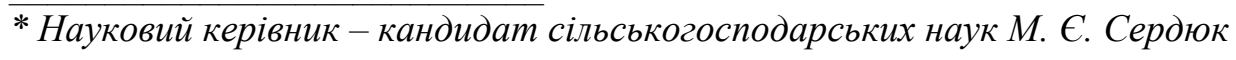


Визначення показників хімічного складу плодів виконували за наступними методиками: масову частку сухих розчинних речовин - рефрактометром [5]; масову частку редукуючих цукрів, сахарози - за ДСТУ4954:2008 [7]; масову частку титрованих кислот - за ДСТУ 4957:2008 [8]; масову частку вітаміну С - за ГОСТ 24556 - 89 [9]. У ході аналізу та обробки експериментальних даних користувалися методами варіаційної статистики: математичну обробку проводили за Ф. Лакіним [3], парний кореляційний аналіз - за Б. А. Доспєховим [2], використовуючи комп`ютерні програми «MS office Excel 2007», пакет «Statistica 6» i персональний комп ютер.

Результати досліджень. Державне підприємство «Дослідне господарство «Мелітопольське» знаходиться у південно-західній частині Мелітопольського району Запорізької області. Район розташований у південній степовій зоні України 3 характерним рівнинним ландшафтом. Клімат даного регіону - атлантично-континентальний із високим температурним режимом. Середньорічна температура повітря становить $9,1-9,9^{\circ} \mathrm{C}$. Абсолютний річний максимум температури становить $39,5^{\circ} \mathrm{C}$ (28.07.1971, 02.08.1998, 07.08.2010). Найтеплішими місяцями $\epsilon$ червень та серпень, із середньомісячними температурами від 20,5 до $23,1{ }^{\circ} \mathrm{C}$. Абсолютний річний мінімум температури (мінус $31{ }^{\circ} \mathrm{C}$ ) відзначався 14 січня 1950 року. Найбільш холодні місяці - січень і лютий, із середньомісячною температурою $2,7-4,5{ }^{\circ} \mathrm{C}$ нижче нуля. Середньорічна сума активних температур вище $10{ }^{\circ} \mathrm{C}$ із квітня по жовтень складає $3316{ }^{\circ} \mathrm{C}$. Погодні умови регіону характеризуються значним перепадом температур у лютому та березні, коли дерева, як правило, виходять із стану вимушеного спокою й можуть пошкоджуватися низькими температурами. Такі температури 3 різкими перепадами характерні й для грудня. Це (разом із заморозками) іноді створює стресові ситуації, що призводять до загибелі врожаїв кісточкових культур. За кількістю опадів район відноситься до зони з недостатнім зволоженням: на рік середня кількість опадів складає 475 мм. Середньорічна вологість повітря - 73 \%. Посушливість клімату обумовлена пануванням сухих північно-східних і східних вітрів. Середньорічна швидкість вітру $-3,7$ м/с. Недостатня кількість вологи в грунті негативно позначається на продуктивності плодових дерев, тому дефіцит вологи можна компенсувати лише за рахунок зрошення, яке, на жаль, у зв'язку з економічними проблемами застосовується тільки у деяких господарствах регіону.

Результати наших досліджень свідчать про нестабільність погодних умов вегетаційних періодів дослідних років (табл. 1).

Формування врожаю 2008 року розпочалося восени 2007 року. Середньомісячна температура жовтня цього року була на $2,6^{\circ} \mathrm{C}$ вищою, листопада - на $1,2^{\circ} \mathrm{C}$ нижчою за середньобагаторічну, а грудня - майже не відрізнялася від неї. Стосовно опадів, то їх кількість у жовтні та листопаді цього року майже не відрізнялася від багаторічної кількості, а в грудні перевищувала на 10,8 міліметра.

Січень 2008 року відрізнявся більш низькою температурою повітря, лютий - вищою від середньобагаторічних показників. Кількість опадів за ці місяці була на 55,4 мм нижче норми. Дерева сливи таку зиму витримали без пошкоджень. Весняний період цього року мало відрізнявся від середніх багаторічних даних за температурою повітря. Перехід середньодобових температур через $10^{\circ} \mathrm{C}$ відбувся у другій декаді квітня. За весняні місяці випало 147,3 мм опадів, тоді як середні багаторічні показники за період складають 113 міліметрів. Літо характеризувалося високими температурами повітря й незначною кількістю опадів. Сума активних температур на час збирання врожаю складала $2942{ }^{\circ} \mathrm{C}$ (табл. 1). Кількість опадів за вегетаційний період становила 153,7 мм, за місяць до збирання плодів сливи - 2,7 мм. ГТК дорівнював 0,52 , що характеризує вегетаційний період 2008 року як період із нестійким зволоженням.

Погодні умови вететаційного періоду плодів сливи

\begin{tabular}{|c|c|c|c|c|c|c|}
\hline \multirow[b]{2}{*}{ Роки } & \multicolumn{2}{|c|}{ Суми активних температур, ${ }^{\circ} \mathrm{C}$} & \multicolumn{2}{|c|}{ Сумарна кількість опадів, мм } & \multicolumn{2}{|c|}{ Гідротермічний коефіцієнл } \\
\hline & $\begin{array}{l}\text { за весь } \\
\text { період }\end{array}$ & $\begin{array}{l}\text { за місяць } \\
\text { до збору }\end{array}$ & $\begin{array}{l}\text { за весь } \\
\text { період }\end{array}$ & $\begin{array}{l}\text { за місяць } \\
\text { до збору }\end{array}$ & $\begin{array}{l}\text { за весь } \\
\text { період }\end{array}$ & $\begin{array}{l}\text { за місяць } \\
\text { до збору }\end{array}$ \\
\hline 2008 & 2942 & 723 & 154 & 2,7 & 0,52 & 0,03 \\
\hline 2009 & 2723 & 585 & 131 & 23,4 & 0,48 & 0,4 \\
\hline 2010 & 3167 & 785 & 252 & 5,6 & 0,79 & 0,07 \\
\hline 2011 & 2647 & 679 & 295 & 30,3 & 1,12 & 0,45 \\
\hline
\end{tabular}


Середньомісячні температури жовтня та листопада 2008 року були на $1,6^{\circ} \mathrm{C}$ вищими, а грудня на $0,5^{\circ} \mathrm{C}$ нижчими за багаторічні.

Перша декада січня 2009 року характеризувалася сильними морозами, а в другій та третій декадах температура повітря була вище середньої багаторічної.

Лютий та березень характеризувалися підвищеними температурами повітря.

Перехід середньодобових температур через $10{ }^{\circ} \mathrm{C}$ відбувся у третій декаді квітня.

У травні 2009 року було відзначене різке й досить тривале зниження температури до негативного рівня (весняні заморозки), що припало на період цвітіння культури i мало негативний вплив на формування майбутнього врожаю.

Середньомісячні температури червня та липня на $2,7^{\circ} \mathrm{C}$ перевищували середні багаторічні температури.

Сума активних температур на час збирання врожаю складала $2723{ }^{\circ} \mathrm{C}$ (табл. 1).

Кількість опадів за вегетаційний період була не високою - 130,6 мм.

Водночас достатньо висока кількість опадів відзначалася за місяць до збирання плодів сливи (23,4 мм).

ГТК за вегетаційний період дорівнював 0,48, що характеризує вегетаційний період 2009 року як період із нестійким зволоженням.

Середньомісячні температури жовтня та листопада 2009 року були на $2,5^{\circ} \mathrm{C}$, а грудня - на $0,8{ }^{\circ} \mathrm{C}$ вищими за багаторічні.

Січень 2010 року характеризувався низькими температурами повітря, а середньомісячні температури лютого і всіх весняних та літніх (особливо) місяців значно перевищували багаторічні.

Причому, 7 серпня був зафіксований абсолютний максимум температур - плюс $41^{\circ} \mathrm{C}$.

Кількість опадів за вегетаційний період 2010 року становила 252 мм, але опади випадали нерівномірно: в травні (в період цвітіння культури) випало 108,3 мм, а за місяць до збирання врожаю - всього 5,6 мм опадів.

ГТК за вегетаційний період дорівнював 0,79, що характеризує вегетаційний період 2010 року як період із недостатнім зволоженням.

Жовтень 2010 року характеризувався низькими температурами (на $2,1{ }^{\circ} \mathrm{C}$ нижче багаторічних) і значними опадами (на 57,4 мм більше багаторічних).

Середньомісячні температури листопада цього року були на $5,7^{\circ} \mathrm{C}$, а грудня - на $2,3{ }^{\circ} \mathrm{C}$ вищими за багаторічні.

Січень, лютий, а також квітень 2011 року ха- рактеризувалися значно нижчими температурами від багаторічних даних.

До того ж низькі температури квітня відсунули початок вегетаційного періоду плодових дерев майже на два тижні.

Негативну роль на якість врожаю 2011 року мала й велика кількість опадів у травні місяці, що припало на період цвітіння.

У цей же період була зафіксована і надмірно висока відносна вологість повітря.

Літні місяці характеризувалися високими температурами повітря й нестабільними опадами.

Кількість опадів за місяць до збирання плодів становила 30,3 мм, а за вегетаційний період 295,4 мм.

Сума активних температур за вегетаційний період 2011 року становила 2647, ГТК - 1,12, що характеризує його як період із достатнім зволоженням.

Отже, кліматичні ресурси дослідного регіону у період із 2008 по 2011 роки були непостійними й значно відрізнялися від багаторічних, що мало негативні наслідки щодо формування врожаю та хімічного складу плодів сливи.

Під час закладання продукції на зберігання нами були визначені показники хімічного складу плодів сливи, які мають найбільший вплив на формування їх якості:

- сухі розчинні речовини (СРP),

- цукри,

- органічні кислоти,

- вітамін С.

Iз даних таблиці 2 видно, що найвищий вміст сухих розчинних речовин та цукрів відзначався у 2008 та 2010 роках, а кислот та вітаміну С у 2009 та 2011 роках.

У результаті кореляційного аналізу (див. рис.) був виявлений тісний позитивний зв'язок між вмістом сухих розчинних речовин і цукрів та сумою активних температур за вегетаційний період ( $\mathrm{r}=$ $0,92 \pm 0,11$ - для CPP, $r=0,76 \pm 0,21$ - для цукрів).

Між кількістю опадів і ГТК вегетаційного періоду й цими показниками тісних кореляційних зв'язків не виявлено.

Ще більш істотний вплив на накопичення СРP i цукрів мали погодні умови останнього місяця перед збиранням врожаю.

Був установлений тісний позитивний зв'язок між кількістю СРР і цукрів та сумою активних температур протягом цього періоду $(\mathrm{r}=0,87 \pm 0,15$ - для СРР, $r=0,96 \pm 0,12$ - для цукрів), а також тісний негативний зв'язок цих показників із кількістю опадів і ГТК $(\mathrm{r}=-0,71 \pm 0,11$ та $\mathrm{r}=-0,76 \pm 0,19$ відповідно для СРP, $\mathrm{r}=-0,66 \pm 0,14$ та $\mathrm{r}=-0,74 \pm 0,12$ 


\section{2. Вміст компонентів хімічного складу плодів сливи сорту Волочка}

\begin{tabular}{|c|c|c|c|c|}
\hline \multirow{2}{*}{$\begin{array}{c}\text { Роки } \\
\text { досліджень }\end{array}$} & \multicolumn{4}{|c|}{ Вміст компонентів } \\
\hline 2008 & СРР, \% & органічні кислоти, \% & цукри, \% & вітамін С, мг/100 г \\
\hline 2009 & $18,535 \pm 0,025$ & $0,478 \pm 0,011$ & $9,515 \pm 0,078$ & $8,897 \pm 0,036$ \\
\hline 2010 & $17,569 \pm 0,015$ & $0,867 \pm 0,035$ & $7,250 \pm 0,010$ & $11,297 \pm 0,089$ \\
\hline 2011 & $18,098 \pm 0,065$ & $0,496 \pm 0,098$ & $10,257 \pm 0,025$ & $9,515 \pm 0,056$ \\
\hline $\mathrm{HIP}_{05}$ & 0,092 & $0,889 \pm 0,078$ & $8,914 \pm 0,097$ & $10,120 \pm 0,021$ \\
\hline
\end{tabular}
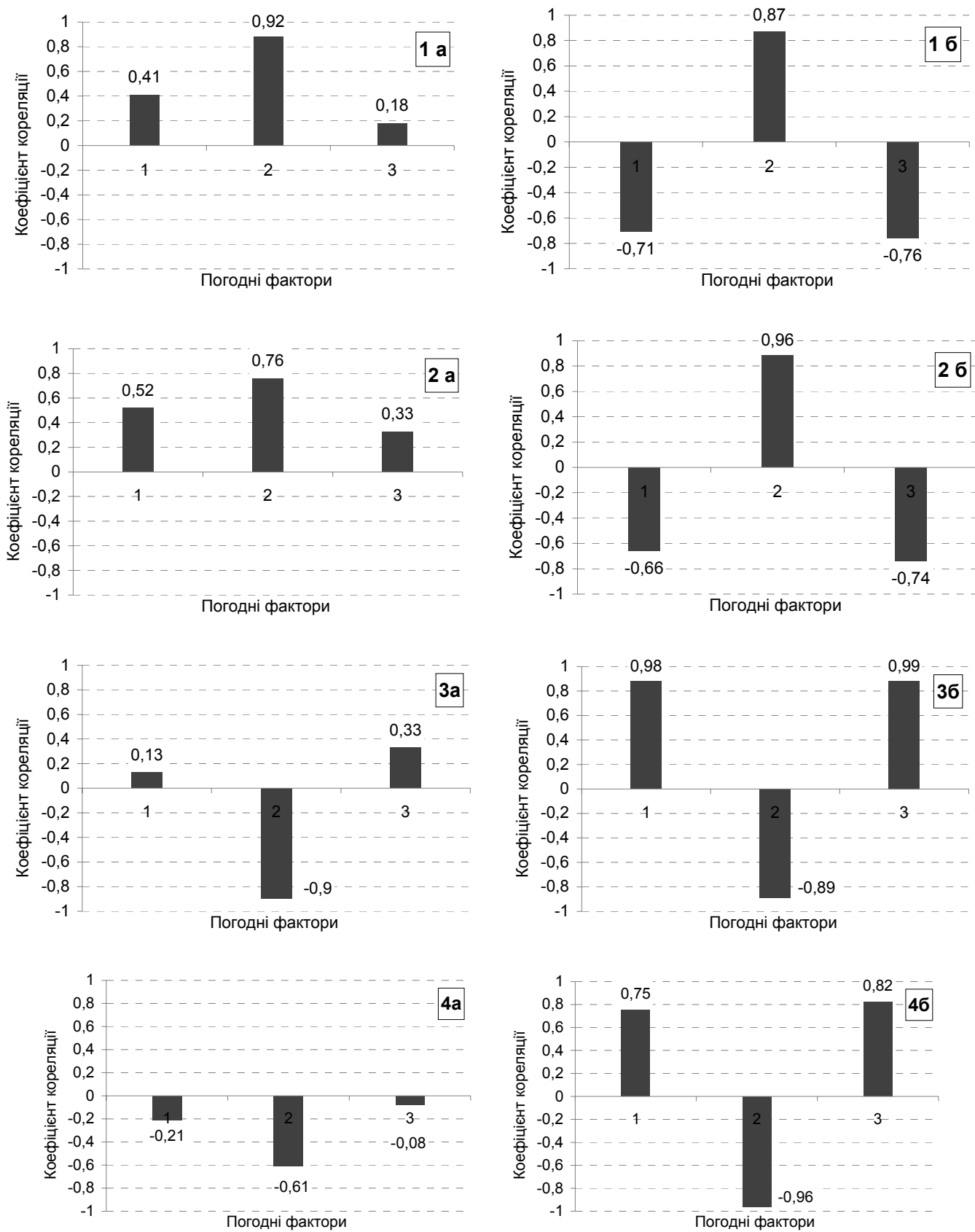

Рис. Кореляційна залежність накопичення СРР (1), вмісту цукрів (2), вмісту органічних кислот (3), вмісту вітаміну С (4) плодів сливи сорту Волочка від погодних умов вететаційного періоду (а) та останнього місяця перед збиранням (в):

1 - кількість опадів, 2 -сума активних температур, 3 -ГТК 
відповідно для цукрів). На накопичення органічних кислот та вітаміну $\mathrm{C}$ більш суттєвий вплив мали погодні умови останнього місяця перед збиранням (див. рис.). Причому між вмістом кислот та сумою активних температур зв'язок був негативним ( $\mathrm{r}=-0,89 \pm 0,11$ - для титрованих кислот, $\mathrm{r}=-0,96 \pm 0,12$ - для вітаміну $\mathrm{C})$, а кількістю опадів та ГТК - позитивним ( $\mathrm{r}=0,98 \pm 0,13$ i $\mathrm{r}=0,99 \pm 0,12$ відповідно для кислот, $\mathrm{r}=0,75 \pm 0,11$ i $\mathrm{r}=0,82 \pm 0,15$ відповідно). Натомість, тісної кореляції між зазначеними показниками та погод-

\section{БІБЛІОГРАФІЯ}

1. Державний реєстр сортів рослин, придатних для поширення в Україні у 2012 році. - К. : Элефа, 2012. $-230 \mathrm{c}$.

2. Доспехов Б. А. Методика полевого опыта (с основами статистической обработки результатов исследований) / Б. А. Доспехов. - М. : Агропромиздат, 1985. - 351c.

3. Лакин Г. Ф. Биометрия / Г. Ф. Лакин. - М. : Высшая школа, 1990. $-352 \mathrm{c}$.

4. Найченко B. М. Залежність деяких показників якості плодів сливи та чорної смородини від погодних умов / В. М. Найченко // Садівництво. 1999. - Вип. 49. - С. 147-153.

5. Найченко В. М. Практикум з технології зберігання і переробки плодів та овочів 3 основами товарознавства / В. М. Найченко. - К. : ФАДА ЛТД, 2001. $-211 \mathrm{c}$.

6. Причко Т. Г. Формирование качественных показателей плодов яблони в зависимости от погодных условий периода вегетации / Т. Г. При- ними умовами всього вегетаційного періоду не було виявлено.

Висновок. Результати кореляційного аналізу дають можливість стверджувати, що найбільш істотний вплив на формування показників хімічного складу плодів сливи в умовах південного Степу України мають не погодні умови всього вегетаційного періоду, а умови останнього місяця перед збиранням плодів, коли найбільш активно відбувається формування їх якості.

чко, Л. Д. Чалая // Плодоводство и виноградарство Юга России. Тематический сетевой электронный научный журнал СКЗНИИС и В. 2012. - № 13(1).

7. Продукти перероблення фруктів та овочів. Методи визначення цукрів. Технічні умови: ДСТУ 4954:2008. - [Чинний від 21.09.09]. - К. : Госпотребстандарт, 2009. - 22 с.

8. Продукти перероблення фруктів та овочів. Методи визначення титрованої кислоти. Технічні умови : ДСТУ 4957:2008. - [Чинний від 1.07.09]. - К. : Госпотребстандарт, 2009. - 14 с.

9. Продукты переработки плодов и овощей. Методы определения витамина С. Технические условия : ГОСТ 24556-89. - [Введ. с 01.01.90]. К. : Госстандарт Украины, 1990. - 18 с.

10. Ширко T. С. Биохимия и качество плодов / Т. С. Ширко, И. В. Ярошевич. - М. : Наука и техника, 1991. - 294 с. 